\title{
Pengaruh model pembelajaran learning cycle 5e dan learning cycle $5 e$ berbantuan media video pembelajaran terhadap hasil belajar siswa pada materi sistem koloid siswa kelas XI SMA Negeri 1 Gondanglegi
}

\author{
Siti Khusnaini Puji Astuti, Endang Budiasih*, Muhammad Su'aidy \\ Universitas Negeri Malang, Jl. Semarang No. 5 Malang, Jawa Timur, Indonesia \\ *Penulis korespondensi, Surel: endang.budiasih.fmipa@um.ac.id
}

Paper received: 01-06-2021; revised: 15-06-2021; accepted: 30-06-2021

\begin{abstract}
Abstrak
Media pembelajaran sangat penting digunakan oleh guru pada saat proses pembelajaran. Penggunaan media seperti ini sangat penting dilakukan untuk memvisualisasikan konsep-konsep yang bersifat abstrak, salah satunya pada materi sistem koloid. Banyak konsep-konsep abstrak pada materi koloid, seperti pada pokok bahasan efek Tyndall, gerak brown, adsorbsi, koloid liofil, dan koloid liofob yang sukar dipahami oleh siswa. Penelitian ini bertujuan untuk mengetahui perbedaan hasil belajar antara siswa yang dibelajarkan dengan model pembelajaran Learning Cycle $5 E$ berbantuan media video pembelajaran dengan siswa yang dibelajarkan dengan model pembelajaran Learning Cycle 5E pada materi sistem koloid. Penelitian ini menggunakan rancangan penelitian eksperimen semu (quasy experiment). Penentuan sampel penelitian dilakukan dengan teknik cluster random sampling. Kelas eksperimen dibelajarkan menggunakan model pembelajaran Learning Cycle $5 E$ berbantuan media video pembelajaran, sedangkan kelas kontrol dibelajarkan dengan model pembelajaran Learning Cycle 5E. Hasil penelitian menunjukkan hasil belajar siswa kelas eksperimen berbeda dengan hasil belajar siswa kelas kontrol, dengan nilai rata-rata kelas eksperimen sebesar 79,84 dan kelas kontrol sebesar 74,27. Hasil belajar afektif dan psikomotorik siswa kelas eksperimen lebih baik dibandingkan hasil belajar siswa kelas kontrol, dengan rata-rata nilai afektif kelas eksperimen dan kontrol masing-masing sebesar 72,92 dan 72,15, sedangkan ratarata nilai psikomotorik kelas eksperimen dan kontrol masing-masing sebesar 85,25 dan 84,93.
\end{abstract}

Kata kunci: Learning Cycle 5E; media video pembelajaran; hasil belajar;sistem koloid

\section{Pendahuluan}

Dewasa ini kita hidup dalam era globalisasi, dimana kemajuan ilmu pengetahuan dan teknologi (IPTEK) telah berkembang begitu pesat. Perkembangan ini memberikan dampak pada berbagai aspek kehidupan manusia, termasuk salah satunya dalam bidang pendidikan. Perkembangan tersebut mempengaruhi kemajuan teknologi pendidikan yang ditandai dengan perkembangan media pembelajaran yang digunakan oleh guru dalam kegiatan pembelajaran di kelas. Perkembangan teknologi ini mengakibatkan adanya perubahan sistem pembelajaran yang diterapkan di sekolah, dimana tidak diterapkannya pembelajaran konvensional yang dianggap kurang menarik bagi siswa. Hal ini karena pembelajaran konvensional menjadikan guru sebagai sumber belajar utama dalam kegiatan pembelajaran di kelas, yang dapat mengakibatkan siswa menjadi pasif dan tidak berperan secara aktif dalam membangun pengetahuan mereka (Suyono \& Hariyanto, 2014).

Media pembelajaran berfungsi untuk menarik dan mengarahkan perhatian siswa agar dapat berkonsentrasi terhadap pelajaran di dalam kelas (Arsyad, 2014). Penggunaan media pembelajaran dalam pembelajaran dapat membangkitkan minat siswa, motivasi, dan rangsangan kegiatan belajar di dalam kelas. Penggunaan media pembelajaran dalam pembelajaran kimia adalah hal yang sangat penting untuk dilakukan oleh guru (Agustina dan 
Novita, 2012). Hal ini karena banyaknya konsep-konsep dalam ilmu kimia yang bersifat abstrak sehingga penggunaan media pembelajaran yang dapat memvisualisasikan konsep yang bersifat abstrak tersebut sangat diperlukan.

Hal lain yang harus diperhatikan oleh guru dalam kegiatan pembelajaran adalah pemilihan strategi dan model pembelajaran yang tepat. Adanya pergeseran paradigma pembelajaran dari behaviorisme menjadi konstruktivisme menyebabkan pembelajaran yang dilakukan di dalam kelas tidak lagi berpusat pada guru (teacher centered), melainkan harus berpusat pada siswa (student centered) (Munifah, 2013). Konstruktivisme merupakan landasan berpikir (filosofi) pembelajaran kontekstual, dimana pengetahuan dibangun oleh manusia sedikit demi sedikit yang hasilnya diperluas (Thobroni, 2015). Pengetahuan bukanlah seperangkat fakta-fakta, konsep, ataupun kaidah yang siap diambil, melainkan manusia harus mengkonstruksi pengetahuan tersebut dan memberi makna melalui pengalaman nyata. Salah satu dari model pembelajaran yang berorientasi pada paradigma konstruktivisme adalah Learning Cycle atau biasa disebut dengan Daur Belajar.

Berdasarkan penelitian yang dilakukan Sulastri (2015) terdapat beberapa kendala yang dialami ketika melakukan pembelajaran menggunakan model pembelajaran Learning Cycle 5E. Dimana pada awal kegiatan pembelajaran, perhatian siswa terhadap penjelasan guru masih kurang maksimal. Hal ini terjadi karena siswa merasa bosan dengan pembelajaran yang dipaparkan guru yang hanya sekedar lisan dan tulisan saja. Oleh karena itu, pada penelitian ini digunakan media video pembelajaran yang bertujuan untuk menarik perhatian siswa dengan menampilkan animasi-animasi yang menarik mengenai mata pelajaran yang akan dipelajari agar siswa tidak merasa bosan ketika melakukan pembelajaran. Selain itu, siswa juga mengalami kesulitan pada tahap exploration. Pada tahap ini siswa mengalami kesulitan ketika mengerjakan pertanyaan-pertanyaan yang terdapat pada LKPD. Hal ini karena siswa belum menguasai konsep yang dipelajari sebelumnya. Oleh karena itu, pada penelitian ini menggunakan media video pembelajaran yang bertujuan agar siswa dapat memahami konsep secara lebih dalam yaitu dengan ditampilkan video pembelajaran yang berisikan mengenai materi yang akan dipelajari oleh siswa. Selain itu, siswa juga mengalami kendala ketika tahap elaboration. Dimana pada tahap ini guru memberikan soal-soal yang bervariasi mengenai materi yang diajarkan. Pada tahap ini, siswa membutuhkan waktu yang lama untuk menyelesaikan soal-soal yang diberikan. Oleh karena itu, pada penelitian ini digunakan media video pembelajaran yang bertujuan agar siswa bisa memahami konsep-konsep yang mereka pelajari secara lebih dalam.

Salah satu materi yang dipelajari di tingkat SMA atau MA kelas XI semester genap adalah sistem koloid. Materi sistem koloid adalah materi yang bersifat hafalan dan berisikan konsep-konsep yang bersifat abstrak sehingga membuat siswa kurang tertarik mempelajarinya (Setiawati, 2013). Konsep yang dipelajari pada materi ini cukup luas, meliputi pengelompokan sistem dispersi, jenis-jenis koloid, sifat-sifat koloid, pembuatan sistem koloid, serta penerapan sistem koloid dalam kehidupan. Materi sistem koloid ini sangat erat kaitannya dengan kehidupan sehari-hari sehingga diharapkan siswa lebih mudah dalam memahami, menganalisis, serta menerapkannya dalam kehidupan. Beberapa konsep abstrak dalam materi koloid yang menekankan pemahaman konseptual terdapat pada pokok bahasan efek Tyndall, gerak brown, adsorbsi, koloid liofil, dan koloid liofob yang sukar dipahami. Konsep-konsep tersebut akan dianggap sulit oleh siswa sehingga dapat menyebabkan siswa malas untuk mempelajari materi koloid yang nantinya akan berakibat 
pada rendahnya hasil belajar yang didapat oleh siswa. Oleh karena itu diperlukan penggunaan media pembelajaran yang dapat memvisualisasikan keabstrakan dari materi koloid tersebut. Salah satunya adalah dengan penggunaan media video pembelajaran.

\section{Metode}

Rancangan yang digunakan pada penelitian ini adalah rancangan penelitian eksperimental semu (quasi eksperimental) dengan menggunakan post-test only control group design. Penelitian ini menggunakan dua kelas, yaitu kelas eksperimen dan kelas kontrol. Kelompok kelas eksperimen adalah kelas yang diberi perlakuan penerapan model pembelajaran Learning Cycle $5 E$ berbantuan video pembelajaran, sedangkan kelompok kelas kontrol adalah kelas yang diberi perlakuan penerapan model pembelajaran Learning Cycle $5 E$ saja.

Penelitian dilakukan di SMA Negeri 1 Gondanglegi. Populasi pada penelitian ini adala seluruh siswa kelas XI program IPA yang terdiri dari lima kelas. Teknik pengambilan sampel yang digunakan dalam penelitian ini adalah Cluster Random Sampling dan didapatkan kelas XI-MIA 5 sebagai kelas eksperimen yang dibelajarkan dengan model pembelajaran Learning Cycle $5 E$ berbantuan video pembelajaran dan kelas XI-MIA 4 sebagai kelas kontrol yang dibelajarkan dengan model pembelajaran Learning Cycle 5E saja.

Instrumen penelitian pada penelitian ini terdapat instrumen perlakuan dan instrumen pengukuran. Instrumen perlakuan berupa silabus, RPP untuk kelas eksperimen dan kontrol, LKS, media video pembelajaran untuk kelas eksperimen. RPP, LKS, dan video telah divalidasi oleh validator sehingga instrumen yang digunakan untuk penelitian adalah instrumen yang valid. Instrumen pengukuran yaitu soal tes hasil belajar, lembar observasi afektif dan psikomotorik siswa.

Analisis data yang dilakukan pada penelitian ini terdapat dua cara, yaitu analisis deskriptif dan analisis statistik. Analisis deskriptif digunakan mendeskripsikan nilai afektif dan nilai psikomotorik pada saat penelitian dilakukan. Analisis statistik pada penelitian ini dilakukan untuk mengetahui perbedaan hasil belajar kognitif siswa dengan bantuan program software Statistical Product and Service Solutions (SPSS 15.0 for windows).

\section{Hasil dan Pembahasan}

\subsection{Kemampuan Awal Siswa}

Data kemampuan awal siswa diperoleh dari nilai Ulangan Tengah Semester siswa pada materi sebelumnya. Data kemampuan awal kelas eksperimen dan kelas kontrol dapat dilihat pada Tabel 3.1

Tabel 3.1 Deskripsi Data Kemampuan Awal Kelas Eksperimen dan Kelas Kontrol

\begin{tabular}{llllll}
\hline Kelas & $\begin{array}{l}\text { Jumlah } \\
\text { Siswa }\end{array}$ & $\begin{array}{l}\text { Nilai } \\
\text { Terendah }\end{array}$ & $\begin{array}{l}\text { Nilai } \\
\text { Tertinggi }\end{array}$ & $\begin{array}{l}\text { Rata- } \\
\text { rata }\end{array}$ & $\begin{array}{l}\text { Standar } \\
\text { Deviasi }\end{array}$ \\
\hline Eksperimen & 32 & 12,00 & 97 & 52,19 & 22,27 \\
Kontrol & 30 & 11,00 & 95 & 47,87 & 23,82 \\
\hline
\end{tabular}

Sebelum dilakukan uji hipotesis, dilakukan uji prasyarat terlebih dahulu yang meliputi uji normalitas dan homogenitas. Uji normalitas dilakukan dengan menggunakan uji Kolmogorov-Smirnov (uji K-S) dengan bantuan program SPSS 15.0 for 
windows. Berdasarkan hasil uji normalitas diperoleh bahwa data kemampuan awal siswa kelas eksperimen memiliki nilai signifikansi sebesar 0,200 (lebih besar dari 0,05) dan data kemampuan awal siswa kelas kontrol sebesar 0,200 (lebih besar dari 0,05 ). Dengan demikian dapat disimpulkan bahwa data kemampuan awal siswa pada kelas eksperimen dan kelas kontrol terdistribusi normal. Selanjutnya dilakukan uji homogenitas. Uji homogenitas dilakukan dengan menggunakan uji Levene dengan bantuan program SPSS 15.0 for windows. Berdasarkan hasil uji normalitas diperoleh bahwa data kemampuan awal siswa pada kelas eksperimen dan kelas kontrol memiliki varian yang sama atau homogen. Hal ini dapat dilihat dari nilai signifikansinya yang sebesar 0,746 (lebih dari 0,05). Setelah data terdistribusi normal dan memiliki varian yang homogen dapat dilanjutkan dengan uji hipotesis, yaitu uji kesamaan dua ratarata. Uji kesamaan dua rata-rata dilakukan dengan menggunakan uji-t dua sampel tidak berhubungan (Independent Sample t-Test) karena data terdistibusi normal dan memiliki varian yang sama (homogen). Analisis dilakukan dengan bantuan program SPSS 15.0 for windows. Berdasarkan hasil uji kesamaan dua rata-rata diperoleh bahwa nilai signifikansinya sebesar 0,463 (lebih besar dari 0,05 ) sehingga dapat disimpulkan bahwa tidak terdapat perbedaan kemampuan awal siswa pada kelas eksperimen dan kelas kontrol.

\subsubsection{Hasil Belajar Kognitif}

Data hasil belajar kognitif siswa diperoleh dari nilai ulangan harian pada materi sistem koloid setelah diberi perlakuan pembelajaran di pertemuan ke enam. Soal ulangan harian terdiri dari 30 soal pilihan ganda. Data hasil belajar kognitif siswa pada kelas eksperimen dan kelas kontrol dapat dilihat pada Tabel 3.2

Tabel 3.2 Data Hasil Belajar Kognitif Siswa

\begin{tabular}{llllll}
\hline Kelas & $\begin{array}{l}\text { Jumlah } \\
\text { Siswa }\end{array}$ & $\begin{array}{l}\text { Nilai } \\
\text { Terendah }\end{array}$ & $\begin{array}{l}\text { Nilai } \\
\text { Tertinggi }\end{array}$ & Rata-rata & $\begin{array}{l}\text { Standar } \\
\text { Deviasi }\end{array}$ \\
\hline Eksperimen & 32 & 60 & 97 & 79,84 & 10,54 \\
Kontrol & 30 & 57 & 90 & 74,27 & 9,71 \\
\hline
\end{tabular}

Analisis data hasil belajar kognitif siswa dilakukan untuk mengetahui apakah terdapat perbedaan hasil belajar kognitif siswa pada kelas eksperimen yang dibelajarkan dengan model pembelajaran $L C-5 E$ berbantuan media video pembelajaran dengan kelas kontrol yang dibelajarkan dengan model pembelajaran $L C$ 5E. sebelum dilakukan uji hipotesis, maka dilakukan uji prasyarat terlebih dahulu yang meliputi uji normalitas dan homogenitas. Berdasarkan hasil uji normalitas diperoleh bahwa data hasil belajar kognitif siswa kelas eksperimen memiliki nilai signifikansi sebesar 0,146 (lebih besar dari 0,05) dan data hasil belajar kognitif siswa kelas kontrol sebesar 0,200 (lebih besar dari 0,05). Dengan demikian dapat disimpulkan bahwa data hasil belajar kognitif siswa pada kelas eksperimen dan kelas kontrol terdistribusi normal. Selanjutnya dilakukan uji homogenitas menggunakan uji Levene. Berdasarkan hasil uji homogenitas diperoleh bahwa data hasil belajar kognitif siswa pada kelas eksperimen dan kelas kontrol memiliki varian yang sama atau homogen. Hal ini dapat dilihat dari nilai signifikansinya sebesar 0,592 (lebih dari 0,05). Setelah data terdistribusi normal dan memiliki varian homogen selanjutnya dapat dilakukan uji 
hipotesis menggunakan uji-t. Hasil uji hipotesis hasil belajar kognitif siswa dapat dilihat pada Tabel 3.3

Tabel 3.3 Hasil Uji Hipotesis Data Hasil Belajar Kognitif Siswa Kelas Eksperimen dan Kelas Kontrol

\begin{tabular}{llll}
\hline Kelas & Nilai Rata-rata & Nilai Signifikansi & Kesimpulan \\
\hline Eksperimen & 79,84 & \multirow{2}{*}{0,035} & \multirow{2}{*}{$\mathrm{H}_{0}$ ditolak } \\
Kontrol & 74,27 & & \\
\hline
\end{tabular}

Berdasarkan Tabel 3.3 dapat dilihat bahwa nilai signifikansi hasil uji-t sebesar 0,035 (kurang dari 0,05) maka dapat disimpulkan bahwa H0 ditolak dan H1 diterima. Berdasarkan hasil tersebut diperoleh bahwa terdapat perbedaan hasil belajar antara siswa yang dibelajarkan dengan model pembelajaran Learning Cycle 5E pada kelas kontrol dan siswa yang dibelajarkan dengan model pembelajaran Learning Cycle 5E berbantuan media video pembelajaran pada kelas eksperimen. Rata-rata nilai hasil belajar ulangan harian pada materi koloid menunjukkan bahwa siswa pada kelas eksperimen memiliki nilai rata-rata yang lebih besar, yaitu sebesar 79,84 lebih tinggi daripada nilai rata-rata siswa pada kelas kontrol sebesar 74,27.

\subsubsection{Hasil Belajar Afektif}

Nilai afektif siswa diperoleh dari pengamatan oleh observer pada saat kegiatan pembelajaran berlangsung. Berdasarkan hasil pengamatan diperoleh rata-rata nilai afektif siswa pada kelas eksperimen dan kelas kontrol yang dapat dilihat pada Tabel 3.4

Tabel 3.4 Rata-rata Nilai Afektif Siswa Kelas Eksperimen dan Kelas Kontrol

\begin{tabular}{lll}
\hline Pertemuan & $\begin{array}{l}\text { Rata-rata Nilai Afektif } \\
\text { Kelas Eksperimen }\end{array}$ & Kelas Kontrol \\
\hline Pertama & 71,18 & 70,37 \\
Kedua & 71,88 & 71,11 \\
Ketiga & 72,92 & 72,60 \\
Keempat & 73,96 & 72,97 \\
Kelima & 74,65 & 73,71 \\
Rata-rata & 72,92 & 72,15 \\
\hline
\end{tabular}

Berdasarkan Tabel 3.4 dapat dilihat bahwa rata-rata nilai afektif siswa pada kelas eksperimen dan kelas kontrol masing-masing sebesar 72,92 dan 72,15 termasuk ke dalam kategori cukup baik.

\subsubsection{Hasil Belajar Psikomotorik}

Hasil belajar psikomotorik siswa diperoleh dari penilaian lembar observasi ketika kegiatan praktikum dilakukan yang dibantu oleh observer. Total skor yang diperoleh oleh tiap siswa dijumlahkan kemudian dihitung rata-rata nilainya pada kelas eksperimen dan kelas kontrol. Rata-rata nilai pengamatan hasil belajar psikomotorik siswa pada kelas eksperimen dan kelas kontrol dapat dilihat pada Tabel 3.5 
Tabel 3.5 Rata-rata Nilai Psikomotorik Siswa Kelas Eksperimen dan Kelas Kontrol

\begin{tabular}{lll}
\hline Kelas & Jumlah Siswa & Nilai Rata-rata \\
\hline Eksperimen & 32 & 85,25 \\
Kontrol & 30 & 84,93 \\
\hline
\end{tabular}

Berdasarkan Tabel 3.5 dapat dilihat bahwa rata-rata nilai psikomotorik siswa pada kelas eksperimen dan kelas kontrol masing-masing sebesar 85,25 dan 84,93 termasuk ke dalam kategori baik. Rata-rata nilai psikomotorik kelas eksperimen sebesar 85,25 lebih tinggi dari rata-rata nilai psikomotorik kelas kontrol yang sebesar 84,93 .

\subsection{Kemampuan Awal Siswa}

Nilai kemampuan awal siswa diperoleh dari data nilai penilaian tengah semester. Untuk mengetahuai kemampuan awal peserta didik pada kelas eksperimen dan kelas kontrol setara atau tidak maka harus dilakukan uji statistik yaitu uji kesamaan dua rata-rata (uji-t). Sebelum diuji kesamaan dua rata-rata maka data harus diuji normalitas dan homogenitas terlebih dahulu sebagai prasyarat uji statistik. Hasil uji prasyarat menyatakan bahwa nilai kemampuan awal siswa terdistribusi normal dan memiliki varians homogen, sehingga dapat dilakukan uji kesamaan dua rata-rata menggunakan statistik parametris yaitu uji independent sample t-test. Hasil uji independent sample t-test menunjukan tidak terdapat perbedaan pada kemampuan awal siswa kelas eksperimen dan kelas kontrol. Maka berdasarkan hasil tersebut nilai hasil belajar kognitif yang diperoleh siswa kelas eksperimen dan kelas kontrol pada materi sistem koloid merupakan hasil dari perlakuan yang diberikan selama penelitian.

\subsubsection{Hasil Belajar Kognitif}

Hasil belajar kognitif siswa pada kelas eksperimen memperoleh nilai rata-rata lebih tinggi $(79,84)$ dibandingkan dengan kelas kontrol $(74,27)$. Proses pembelajaran yang dilaksanakan pada kelas eksperimen dan kelas kontrol sama-sama menggunakan model pembelajaran Learning Cycle 5E. Perbedaannya adalah pada kelas eksperimen digunakan media video pembelajaran ketika kegiatan belajar dilakukan. Penggunaan media video pembelajaran ini sangat membantu siswa dalam memahami materi yang diberikan, dimana dengan adanya video pembelajaran tersebut dapat memvisualisasikan materi yang dipelajari sehingga pemahaman siswa tentang materi sistem koloid dapat tertata dan terstuktur dengan baik. Selain itu, penggunaan media video pembelajaran juga dapat meningkatkan minat siswa dalam belajar. Adanya video yang ditayangkan oleh guru dapat membuat siswa tidak mudah bosan ketika mengikuti pembelajaran di dalam kelas sehingga hal ini akan meningkatkan hasil belajar yang didapatkan oleh siswa. Hal ini sejalan dengan penelitian yang dilakukan oleh Atika (2018) yang memberikan hasil bahwa penggunaan model pembelajaran dengan berbantuan video dapat meningkatkan hasil belajar kognitif siswa. Adanya video dalam proses pembelajaran dapat memberikan ketertarikan bagi siswa untuk dapat terlibat secara aktif dalam pembelajaran. 


\subsubsection{Hasil Belajar Afektif}

Hasil belajar afektif siswa pada kelas eksperimen dan kelas kontrol juga menunjukkan perbedaan. Rata-rata nilai afektif siswa pada kelas eksperimen yakni sebesar 72,92 lebih besar dari rata-rata nilai afektif siswa pada kelas kontrol yakni sebesar 72,15. Rata-rata nilai afektif pada kedua kelas termasuk ke dalam kategori cukup baik. Adanya perbedaan rata-rata nilai afektif pada kedua kelas karena adanya penggunaan video pada kelas eksperimen yang dapat merangsang siswa untuk bertanya mengenai materi yang sedang dipelajari. Selain itu siswa juga lebih memiliki keinginan dalam menyampaikan ide atau pendapat mereka daripada siswa pada kelas yang tidak menggunakan video pembelajaran. Akibatnya, nilai afektif yang didapatkan oleh siswa pada kelas eksperimen lebih tinggi dibandingkan dengan nilai afektif siswa pada kelas kontrol. Penggunaan media video dalam kegiatan belajar sangat dapat memotivasi siswa dalam proses belajar sehingga hal ini dapat mempengaruhi hasil belajar yang didapatkan oleh siswa. Hal ini sejalan dengan penelitian yang dilakukan oleh Liswijaya (2012) yang memberikan hasil bahwa penggunaan media pembelajaran seperti media video dalam pembelajaran kimia dapat meningkatkan motivasi dan hasil belajar siswa, dimana siswa merasa senang dan antusias dalam mengikuti kegiatan belajar mengajar di dalam kelas. Hal ini juga dipertegas oleh Odera (2011) yang mengatakan bahwa menggunakan media pendidikan dan teknologi seperti media video dapat memotivasi siswa dalam belajar, dimana penggunaan media dapat memberikan pengaruh besar pada saat pembelajaran berlangsung.

\subsubsection{Hasil Belajar Psikomotorik}

Hasil belajar psikomotorik siswa pada kelas eksperimen dan kelas kontrol memiliki perbedaan yang tidak signifikan, namun nilai psikomotorik siswa pada kelas eksperimen masih lebih tinggi jika dibandingkan nilai psikomotorik siswa pada kelas kontrol. Hal ini karena kegiatan percobaan yang dilakukan oleh siswa hanya pada dua topik, yaitu pengelompokan campuran dan pembuatan koloid. Tidak banyaknya percobaan yang dilakukan mengakibatkan nilai yang didapatkan oleh siswa kelas eksperimen dan kelas kontrol tidak jauh berbeda. Siswa kelas eksperimen memiliki rata-rata nilai psikomotorik sebesar 85,25 lebih tinggi dibandingkan rata-rata nilai psikomotorik siswa pada kelas kontrol yakni sebesar 84,93. Rata-rata nilai psikomotorik pada kedua kelas termasuk ke dalam kategori baik. Berdasarkan hal tersebut dapat disimpulkan bahwa nilai psikomotorik siswa pada kelas eksperimen adalah lebih baik daripada siswa pada kelas kontrol. Hal ini menunjukkan siswa pada kelas eksperimen lebih baik dalam melakukan kegiatan praktikum. Hal ini sesuai dengan kelebihan yang dimiliki oleh media video pembelajaran yang digunakan, dimana dapat menampilkan video tentang percobaan atau eksperimen sehingga siswa dapat memperoleh pengetahuan mengenai ketrampilan penggunaan alat praktikum sesuai dengan prosedur yang ada. Hal ini sejalan dengan penelitian yang dilakukan Izzudin (2013) bahwa penggunaan media video interaktif dalam pembelajaran dapat meningkatkan hasil belajar praktik siswa pada materi service engine dan komponenkomponennya. Dengan demikian dapat disimpulkan bahwa penggunaan media video interaktif sangat efektif digunakan saat pembelajaran berlangsung. 


\section{Simpulan}

4.1. Hasil belajar siswa yang dibelajarkan dengan model pembelajaran Learning Cycle $5 E$ berbantuan media video pembelajaran berbeda dengan hasil belajar siswa yang dibelajarkan dengan model pembelajaran Learning Cycle 5E. Hasil belajar kognitif siswa kelas eksperimen lebih tinggi dibandingkan kelas kontrol. Hasil belajar siswa kelas eksperimen lebih tinggi dibandingkan kelas kontrol dengan rata-rata nilai hasil belajar kognitif siswa kelas eksperimen lebih tinggi $(79,84)$ dibandingkan hasil belajar siswa kontrol $(74,27)$.

4.2. Hasil belajar afektif dan psikomotorik siswa yang dibelajarkan dengan model pembelajaran Learning Cycle $5 E$ berbantuan media video pembelajaran lebih baik dibandingkan hasil belajar siswa yang dibelajarkan dengan model pembelajaran Learning Cycle 5E. Rata-rata nilai afektif kedua kelas tergolong cukup baik, dimana nilai afektif siswa kelas eksperimen lebih tinggi $(79,92)$ dibandingkan kelas kontrol $(72,15)$, sedangkan untuk rata-rata nilai psikomotorik kelas eksperimen lebih tinggi $(85,25)$ dibandingkan kelas

4.3. kontrol $(84,93)$ dan nilai psikomotorik di kedua kelas tergolong baik.

\section{Ucapan Terima Kasih}

Penelitian ini tidak dapat terlaksana dengan baik tanpa bantuan dari berbagai pihak. Terima kasih penulis ucapkan kepada Dr. Hj. Endang Budiasih, M.S. selaku dosen pembimbing I dan Drs. Muhammad Su'aidy, M.Pd. selaku dosen pembinbing II yang telah memberikan bimbingan dan saran selama proses penelitian dan penulisan laporan penelitian. Dr. Munzil, S.Pd., M.Si. selaku ketua dewan penguji yang telah memberikan saran-saran perbaikan pada penulisan laporan hasil penelitian. Guru kimia SMA Negeri 1 Gondanglegi Sulistyoningsih, S.Pd dan Ari Sumarliani S.Pd yang telah menjadi validator pada instrument penelitian. Drs. Sugiono, M.Pd. selaku Kepala SMA Negeri 1 Gondanglegi yang telah memberikan izin kepada penulis melaksanakan penelitian ini di sekolah.

\section{Daftar Rujukan}

Agustina, A. (2012). Pengembangan media pembelajaran video untuk melatih kemampuan memecahkan masalah pada materi larutan asam basa (Development Of Learning Media Experience To Win Chemistry Based On Computer For Orientation Problem Solving At Acid Base Solution). UNESA journal of chemical education, 1(1).

Arikunto, S. (2014). Prosedur penelitian: Suatu pendekatan praktik. Rineka cipta.

Azhar, A. (2014). Media pembelajaran, Jakarta: PT. Raja Grafindo Persada.

Atika, D., Nuswowati, M., \& Nurhayati, S. (2018). Pengaruh metode discovery learning berbantuan video terhadap hasil belajar kimia siswa SMA. Jurnal Inovasi Pendidikan Kimia, 12(2).

Dasna, I. W. (2005, September). Kajian implementasi model siklus belajar (Learning Cycle) dalam pembelajaran kimia. In makalah seminar nasional MIPA dan pembelajarannya. FMIPA UM-Dirjen Dikti Depdiknas (Vol. 5).

Fajaroh, F., Dasna, I. W. (2007). Pembelajaran dengan model siklus belajar (learning cycle). Universitas Negeri Malang. Malang.

Izzudin, A. M. (2013). Efektivitas penggunaan media pembelajaran video interaktif untuk meningkatkan hasil belajar praktik service engine dan komponen-komponennya (Doctoral dissertation, Universitas Negeri Semarang). 
Liswijaya. (2012) pengembangan media pembelajaran kimia berbantuan komputer pada materi reaksi reduksi oksidasi untuk meningkatkan motivasi dan hasil belajar peserta didik SMA/MA kelas X. S2 thesis, UNY.

Munifah, A. K. (2013). Pengaruh model pembelajaran learning cycle 5 fase berbantuan media berbasis audio visual terhadap hasil belajar dan motivasi belajar siswa kelas XI SMA Negeri 7 Malang pada materi larutan penyangga (Doctoral dissertation, Universitas Negeri Malang).

Odera, F. Y. (2011). Motivation: The most ignored factor in classroom instruction in Kenyan secondary schools. International journal of Science and Technology, 1(6), 283-288.

Setiawati, N. T., \& Nugroho, A. (2013). Studi komparasi tipe STAD dan TGT pada materi koloid ditinjau dari kemampuan memori siswa kelas XI SMA Negeri 2 Karanganyar Tahun 2011/2012. Jurnal pendidikan kimia, 2(1).

Sugiyono, P. D. (2017). Metode penelitian pendidikan: pendekatan kuantitatif, kualitatif, R\&D. Bandung: CV Alfabeta.

Sulastri, E., Mariani, S., \& Mashuri, M. (2015). Studi perbedaan keefektifan pembelajaran LC-5E dan CIRC terhadap kemampuan pemecahan masalah matematika. Kreano, Jurnal Matematika KreatifInovatif, 6(1), 26-33.

Suyono, Hariyanto. (2014). Belajar dan pembelajaran : Teori dan konsep dasar. Bandung: PT Remaja Rosdakarya

Thobroni, M. (2015). Belajar dan pembelajaran teori dan praktik. Yogyakarta: Ar-Ruzz Media. 